\title{
Biochemistry of Water Soluble Vitamins, Sources, Biochemical Functions and Toxicity
}

\author{
Hamza Rafeeq ${ }^{1}$, Irha Basit ${ }^{1 *}$, Rizwana Jabeen ${ }^{1}$, Iqra Shehzadi ${ }^{1}$, Kanwal Shafique ${ }^{1}$, Sobia Tariq ${ }^{1}$, Qurat ul Ain Naseer ${ }^{2}$, \\ Hafiza Mariyem Raheem ${ }^{1}$
}

${ }^{1}$ Department of Biochemistry, University of Agriculture, Faisalabad, Pakistan

${ }^{2}$ Department of Biochemistry, Government College University, Faisalabad, Pakistan

DOI: $\underline{10.36348 / \mathrm{sijb} .2020 . \mathrm{v} 03 \mathrm{i} 10.003}$

| Received: 28.09.2020 | Accepted: 12.10.2020 | Published: 21.10 .2020

*Corresponding author: Irha Basit

\section{Abstract}

There are thirteen vitamins in humans: four fat soluble (A, D, E, and K) and nine water soluble (vitamin B complex and vitamin $\mathrm{C}$ ). Water-soluble vitamins dissolve rapidly in water and are usually easily excreted by the body. Because they are not processed too soon, a steady intake is important. B vitamin supplements available for each vitamin: B1: thiamine, B2: riboflavin, B3: niacin, etc. Niacin, pantothenic acid, biotin and folate are recognized by name rather than by quantity. $\mathrm{B}$ vitamins are usually used in energy drinks and many are advertised with high levels of B vitamins boasting that they can 'go through the day and do not feel nervous or anxious. B vitamins are primarily absorbed in foods such as pork, fish and liver. Healthy vitamin B sources include vegetables (pulses or beans), whole grains, rice, bananas, chilli pepper, tempeh, brewer's yeast and molasses. While beverage yeast has been used to produce beer, its bioavailability varies from low to adverse, as drinking ethanol hinders the absorption of thiamine (B1), riboflavin (B2), niacin (B3), biotin (B7) and folic acid (B9). Vitamin C is needed for tissue growth and repair in all areas of the body. It is used as an essential protein for the development, repair and maintenance of cartilage, bones and teeth and assists in the absorption of iron.

Keywords: Vitamins, water soluble vitamins, Vitamin C, Vitamin B1, folate.

Copyright $\odot 2020$ The Author(s): This is an open-access article distributed under the terms of the Creative Commons Attribution 4.0 International License (CC BY-NC 4.0) which permits unrestricted use, distribution, and reproduction in any medium for non-commercial use provided the original author and source are credited.

\section{INTRODUCTION}

Vitamins are either water-soluble or fatsoluble. Many vitamins do not exist in individual molecules, but belong to similar classes known as vitamers. Vitamin $\mathrm{E}$, for instance, comprises 4 tocopherols and 4 tocotrienols. There are thirteen vitamins in humans: four fat soluble (A, D, E, and $\mathrm{K}$ ) and nine water soluble (vitamin $\mathrm{B}$ complex and vitamin C). Water-soluble vitamins dissolve rapidly in water and are usually easily excreted by the body. Because they are not processed too soon, a steady intake is important. Fat soluble vitamins are processed through the intestine using lipids (fats). The body can accumulate vitamins $\mathrm{A}$ and $\mathrm{D}$ that can lead to dangerous hypervitaminosis. Fat-soluble malabsorption vitamin deficiency is especially important in cystic fibrosis [1].

B vitamins are a class of water-soluble vitamins that are important to cell metabolism [2, 3]. Although they have common names, these vitamins are chemically different compounds that coexist in the same food. Eight dietary supplements are generally referred to as vitamin B complexes $[4,5]$. The highest concentration of $\mathrm{B}$ vitamins can be found in meat. These can also be used in limited quantities in whole unprocessed carbohydrate-dependent foods. The level of vitamin B found in refined carbohydrates, including sugar or white grain, is lower than the amount of natural fuel [6].

Vitamin C is a vital nutrient for some animals, including humans. Vitamin $\mathrm{C}$ contains different vitamins that produce vitamin $\mathrm{C}$ in animals. Some of the food supplements contain ascorbate salts, including sodium ascorbate and calcium ascorbate. These releases are processed through digestion. Ascorbate and ascorbic acid are naturally found within the body as forms interconverted by $\mathrm{pH}$. Dehydroascorbic acid is converted by reducing agents to ascorbic acid in oxidised molecular forms [7]. 
Table-1: An overview of water soluble vitamins

\begin{tabular}{|c|c|c|c|c|}
\hline Vitamin & Function & Deficiency & Dietary source & RDA (Adult male/female) \\
\hline $\begin{array}{lr}\text { Vitamin } & \text { B } \\
\text { complex } & (\mathbf{B 1}, \\
\text { B2, B3, B5, } \\
\text { B6, B7, B9 } \\
\text { and B12) }\end{array}$ & Act as co-enzymes & $\begin{array}{l}\text { Mostly } \\
\text { cause } \\
\text { serious } \\
\text { diseases }\end{array}$ & $\begin{array}{l}\text { Meat, vegetable, nuts, } \\
\text { eggs, pasta, bread, cerals } \\
\text { etc }\end{array}$ & $\begin{array}{l}\text { B1 }(1.2 \mathrm{mg} / 1.1 \mathrm{mg}) \\
\text { B2 }(1.3 \mathrm{mg} / 1.1 \mathrm{mg}) \\
\text { B3(16 mg/14 mg) } \\
\text { B5 }(16 \mathrm{mg} / 14 \mathrm{mg}) \\
\text { B6 }(1.3-1.7 \mathrm{mg} / \\
1.2-1.5 \mathrm{mg}) \\
\text { B7 }(30 \mu \mathrm{g}) \\
\text { B9 }(400 \mu \mathrm{g}) \\
\text { B12 }(2.4 \mu \mathrm{g})\end{array}$ \\
\hline Vitamin C & $\begin{array}{l}\text { Growth and repair of } \\
\text { tissues. } \\
\text { Heal wounds. } \\
\text { Aid in Fe absorption. } \\
\text { Act as antioxidant. }\end{array}$ & Scurvy & $\begin{array}{l}\text { Citrus fruits } \quad \text { and } \\
\text { vegetables, liver }\end{array}$ & $90 \mathrm{mg} / 75 \mathrm{mg}$ \\
\hline
\end{tabular}

\section{Water Soluble Vitamins \\ Vitamin B}

Basic numbers or names of each vitamin are given as individual B vitamin supplements for each vitamin: B1: thiamine, B2: riboflavin, B3: niacin, etc. Niacin, pantothenic acid, biotin and folate are recognised by name rather than by quantity. Each $\mathrm{B}$ vitamin is either a cofactor (usually a coenzyme) or a precursor to major metabolic processes [2].

Consequently, following elimination by regulation in different countries (including the United States), B vitamins thiamine, riboflavine, niacin and folic acid must be incorporated into white flour. It is often referred to on food labels as enriched flour. B vitamins are primarily absorbed in foods such as pork, fish and liver. Healthy vitamin B sources include vegetables (pulses or beans), whole grains, rice, bananas, chilli pepper, tempeh, brewer's yeast and molasses. While beverage yeast has been used to produce beer, its bioavailability varies from low to adverse, as drinking ethanol hinders the absorption of thiamine (B1), riboflavin (B2), niacin (B3), biotin (B7) and folic acid (B9). In addition, one of the previous studies highlights that high intakes of beer and other alcoholic beverages result in a net B deficiency and a health risk of these deficits [3].

Vitamin B12 cannot be present in excess of plant products, which makes B12 deficiency a valid vegetarian problem. Plant-based food producers often report B12 materials, giving rise to doubts as to which sources supply B12. Confusion is caused by the inability to quantify B12 directly with the US Normal
Pharmacopeia (USP) process. The bacterial reaction to food is measured instead. Chemical B12 vitamin derivatives are useful for bacteria present in plant foods, but cannot be used in the human body. Similarly, B12 levels may also be over-reported in other food categories as a result [4].

The use of dietary supplements is a common way of improving the consumption of vitamin B. B vitamins are usually used in energy drinks and many are advertised with high levels of B vitamins boasting that they can 'go through the day and do not feel nervous or anxious.' Some nutritionists critically argue, for example, that while B vitamins 'help to transfer energy to food,' most Americans have the necessary supplements to supplement B vitamins [5].

Excess B vitamins are usually easily excreted because they are water soluble, although absorption, use and metabolism may vary from person to person. Elderly people and athletes will need to add B12 and other B vitamins to their diets due to absorption difficulties and improved energy output requirements. B vitamins, in particular B12, can also be administered by injection to reverse deficits in cases of extreme deficiency. It is also recommended that thiamine be replaced for type 1 and type 2 diabetes, depending on the elevated prevalence of low plasma thiamine levels and increased thiamine clearance. In addition, early embryo development deficiencies in vitamin B9 (folic acid) have been associated with neural tube defects. Women's pregnancy is therefore generally recommended to increase the consumption and/or replacement of folic acid in their normal diet [8-10]. 
Table-2: Vitamin B complex structure, function and sources

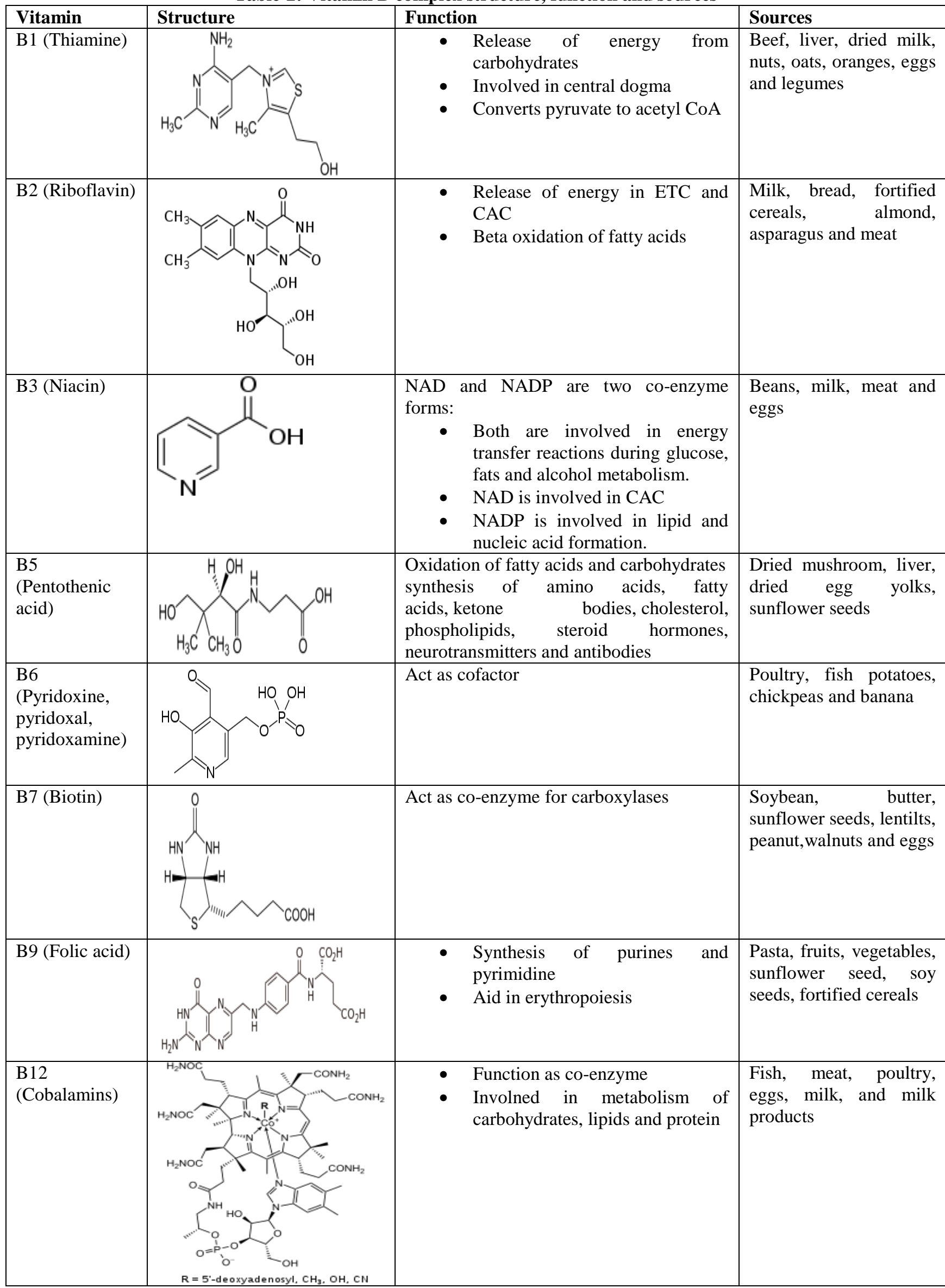


Table-3: Indication of vitamin B complex deficiency, toxicity and absorption

\begin{tabular}{|c|c|c|c|}
\hline Vitamin & Deficiency & Toxicity & Absorption \\
\hline B1 (Thiamine) & $\begin{array}{ll}\text { - } & \text { Beriberi } \\
\text { - } & \text { Wernicke } \\
\text { encephalopathy } \\
\text { - } & \text { Edema } \\
\text { - } & \text { Dementia }\end{array}$ & Not reported & $\begin{array}{l}\text { Absorbed through jejunum and } \\
\text { intestinal mucosal cells through } \\
\text { active and passive transport }\end{array}$ \\
\hline B2 (Riboflavin) & $\begin{array}{ll}\text { - } & \text { Ariboflavinosis } \\
\text { - } & \text { Cheilosis } \\
\text { - } & \text { Glossitis } \\
\text { - } & \text { Seborrheic dermatitis } \\
\text { - } & \text { Pharyngitis } \\
\end{array}$ & $\begin{array}{l}\text { Rare. } \\
\text { Damage liver. }\end{array}$ & $\begin{array}{l}\text { Absorbed in proximal small } \\
\text { intestine }\end{array}$ \\
\hline B3 (Niacin) & - $\quad$ Pellagra & $\begin{array}{l}\text { Liver damage. } \\
\text { Glucose Intolerance. } \\
\text { Hyperuricemia. } \\
\text { Macular edema Macular cysts }\end{array}$ & $\begin{array}{l}\text { Primaril absorbed in small } \\
\text { intestine. Some quantity is } \\
\text { absorbed in stomach. }\end{array}$ \\
\hline $\begin{array}{l}\text { B5 (Pentothenic } \\
\text { acid) }\end{array}$ & $\begin{array}{ll}- & \text { Acne } \\
- & \text { Paresthesia }\end{array}$ & Not reported & 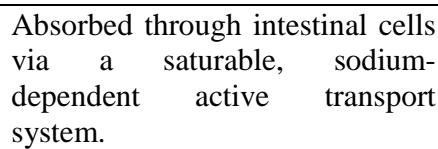 \\
\hline $\begin{array}{l}\text { B6 } \\
\text { (Pyridoxine, } \\
\text { pyridoxal, } \\
\text { pyridoxamine) }\end{array}$ & $\begin{array}{ll}\text { - } & \text { Seborrhoeic dermatitis } \\
\text { - } & \text { Epilepsy } \\
\text { - } & \text { Pink eyes } \\
\end{array}$ & $\begin{array}{l}\text { Ataxia, heartburn, nausea, skin lesions, } \\
\text { photosensitivity and numbness }\end{array}$ & $\begin{array}{l}\text { Absorbed in jujenum through } \\
\text { passive difussion }\end{array}$ \\
\hline B7 (Biotin) & $\begin{array}{ll}\text { Growth and neurological } \\
\text { disorders in infants }\end{array}$ & Eosinophilic pleuropericardial effusion & Absorbed through small intestine \\
\hline B9 (Folic acid) & Macrocytic anemia & $\begin{array}{l}\text { Sleep disturbances, mental confusion, } \\
\text { skin reactions, loss of appetite, nausea, } \\
\text { seizures and gastrointestinal defects }\end{array}$ & $\begin{array}{l}\text { Absorbed primarily in the } \\
\text { duodenum and jejunum within } \\
\text { the acid microenvironment at the } \\
\text { cell surface }\end{array}$ \\
\hline $\begin{array}{l}\text { B12 } \\
\text { (Cobalamins) }\end{array}$ & $\begin{array}{ll}\text { - } & \text { Macrocytic anemia } \\
\text { - } & \text { Pernicious anemia }\end{array}$ & Acne and rosacea & Absorbed through ileum \\
\hline
\end{tabular}

\section{Vitamin C}

The first vitamin C was discovered in 1912, isolated in 1928, and first chemically developed in 1933. The safest and most effective medicines needed in the health care system are on the World Health Organization list of essential medicines. Vitamin $\mathrm{C}$ is used as a low-cost prescription drug. The 1937 Nobel Prize in Physics and Medicine and Chemistry was awarded to Albert Szent-Györgyi and Walter Norman Haworth for his research. Citrus fruits, kiwi-fruits, guava, broccoli, sprouts, bell peppers and strawberries are foods containing vitamin C. Long storage or cooking of food can reduce vitamin $\mathrm{C}$ levels $[11,12]$.

\section{Functions}

Vitamin C is needed for tissue growth and repair in all areas of the body. It is used as an essential protein for the development, repair and maintenance of cartilage, bones and teeth and assists in the absorption of iron. It provides flesh, tendons, ligaments and blood vessels, heals wounds and shapes skin tissues. Vitamin $\mathrm{C}$ is one of many antioxidants. Antioxidants are nutrients that prevent damage to some free radicals. Free radicals are produced when your body breaks down food or when you are exposed to cigarette smoke or radiation. Free radicals develop over time, and the ageing process is a key factor. Free radicals can be critical in conditions such as cancer, heart disease and arthritis. Vitamin $\mathrm{C}$ has been a common cold treatment in the history for several years. Data indicate that most people are not at risk from the common cold of vitamin C supplements or vitamin C-rich foods. However, people who take vitamin $\mathrm{C}$ supplements on a daily basis may experience milder effects or marginally shorter colds. It does not seem necessary to take a vitamin C supplement at the start of the cold [13, 14].

\section{Sources}

Both fruits and vegetables have vitamin $\mathrm{C}$ content. Cantaloupe, citrus fruits and juices such as orange and grapefruit, kiwi fruit, strawberry, papaya, pineapple, beer, raspberries and watermelon provide the highest amount of vitamin $C[15,16]$. Veggies with the highest levels of vitamin $\mathrm{C}$ include: broccoli, sprouts and cauliflower in Brussels, green and red peppers, lettuce, spinach, turnip greens and other leafy greens, tomatoes and tomato juice, squash in winter. Few cereals and other foods and drinks include fortified vitamin C. Fortified indicates that the product has been supplemented with vitamins or mineral [17-20].

Cooking or preserving foods rich in vitamin $\mathrm{C}$ will reduce the amount of vitamin $\mathrm{C}$ for a long time. Vitamin C-rich foods can reduce the loss of cooking by microwaving and steaming. Uncooked or processed fruit and vegetables are the safest food sources for vitamin C. Light sensitivity can also reduce vitamin C 
levels. Choose an orange juice preserved in a box instead of a clear bottle [21].

\section{Deficiency}

Vitamin C deficiency is referred to as Scurvy. It can cause anaemia, fatigue and vomiting, sudden haemorrhage, pain in the arms and legs, swelling in the body, often gum ulceration and loss of teeth [22].

\section{Toxicity}

Vitamin $\mathrm{C}$ is a water-soluble vitamin that does not consume dietary excesses and quickly excretes from the blood into the urine and therefore has a relatively low acute toxicity. More than two or three gm of indigestion will occur, especially if the stomach is empty [23]. However, vitamin $\mathrm{C}$ can minimise this effect in the form of sodium ascorbate and calcium ascorbate. Other symptoms reported at large doses include nausea, abdominal cramps and diarrhoea. The osmotic influence of vitamin $\mathrm{C}$ flowing through the intestine is responsible for these effects. Theoretically, high vitamin $\mathrm{C}$ intake can contribute to a lack of iron absorption [24]. This issue has never been recorded in a review of supplementary tests for healthy subjects, but the likelihood that people with hereditary hemochromatosis may suffer adversely has not been demonstrated [25-28].

\begin{abstract}
Absorption
Active transport and simple diffusion absorbs ascorbic acid throughout the body. The two protein carriers necessary for active absorption are sodiumdependent active transport -Sodium Ascorbate CoTransporters (SVCTs) and Hexose (GLUTs). The reduced form of ascorbate is transported through the plasma membrane by SVCT1 and SVCT2. Glucose transporters are GLUT1 and GLUT3 and pass vitamin C dehydroascorbic acid (DHA) only. Although dehydroascorbic acid is more absorbed than ascorbate in normal plasma and tissues, dehydroascorbic acid is rapidly converted into ascorbate [29, 30].
\end{abstract}

\section{CONCLUSION}

There are different functions of water soluble vitamins. Excretion of some water soluble vitamins and ascorbic acid may be caused by urine. In individuals, vitamin $\mathrm{C}$ is reabsorbed by the kidneys instead of excreted during periods of reduced dietary intake. Reabsorption reduces and excess volumes can easily enter the urine only when plasma concentrations are $1.4 \mathrm{mg} /$ $\mathrm{dL}$ or higher. This recovery will prolong the onset of the shortcoming. Humans are better at turning DHA back into ascorbate than guinea pigs and thus lowering the risk of vitamin $\mathrm{C}$ deficiency and other water soluble viatmins.

\section{REFERENCES}

1. Aguilera-Méndez, A., Fernández-Lainez, C., Ibarra-González, I., \& Fernandez-Mejia, C.
(2012). The chemistry and biochemistry of niacin (B3). In B Vitamins and Folate (pp. 108-126).

2. Angeline, M. E., Gee, A. O., Shindle, M., Warren, R. F., \& Rodeo, S. A. (2013). The effects of vitamin $\mathrm{D}$ deficiency in athletes. The American journal of sports medicine, 41(2), 461-464.

3. Asard, H., May, J., \& Smirnoff, N. (Eds.). (2003). Vitamin C: its functions and biochemistry in animals and plants. Garland Science.

4. Azzi, A. (2018). Many tocopherols, one vitamin E. Molecular aspects of medicine, 61, 92-103.

5. Bellows, L., \& Moore, R. (2012). Water-soluble vitamins: B-complex and vitamin C. Fact sheet (Colorado State University. Extension). Food and nutrition series; no. 9.312

6. Brion, L. P., Bell, E. F., \& Raghuveer, T. S. (2003). Vitamin E supplementation for prevention of morbidity and mortality in preterm infants. Cochrane Database of Systematic Reviews, (4).

7. Calvo, M. S., Whiting, S. J., \& Barton, C. N. (2005). Vitamin D intake: a global perspective of current status. The Journal of nutrition, 135(2), 310-316.

8. Doherty, J. U., Gluckman, T. J., Hucker, W. J., Januzzi, J. L., Ortel, T. L., Saxonhouse, S. J., \& Spinler, S. A. (2017). 2017 ACC expert consensus decision pathway for periprocedural management of anticoagulation in patients with nonvalvular atrial fibrillation: a report of the American College of Cardiology Clinical Expert Consensus Document Task Force. Journal of the American College of Cardiology, 69(7), 871-898.

9. Gast, G. C. M., de Roos, N. M., Sluijs, I., Bots, M. L., Beulens, J. W., Geleijnse, J. M., ... \& van der Schouw, Y. T. (2009). A high menaquinone intake reduces the incidence of coronary heart disease. Nutrition, Metabolism and Cardiovascular Diseases, 19(7), 504-510.

10. Mack, M., \& Grill, S. (2006). Riboflavin analogs and inhibitors of riboflavin biosynthesis. Applied microbiology and biotechnology, 71(3), 265-275.

11. Maqbool, A., \& Stallings, V. A. (2008). Update on fat-soluble vitamins in cystic fibrosis. Current opinion in pulmonary medicine, 14(6), 574-581.

12. Mucida, D., Park, Y., Kim, G., Turovskaya, O., Scott, I., Kronenberg, M., \& Cheroutre, H. (2007). Reciprocal TH17 and regulatory $\mathrm{T}$ cell differentiation mediated by retinoic acid. science, 317(5835), 256-260.

13. Rafeeq, H., Arshad, M. A., Amjad, S. F., Ullah, M. H., Muhammad, H., Imran, R. K., ... \&amp; Ajmal, H. Effect of Nickel on Different Physiological Parameters of Raphanus Sativus.

14. Rafeeq, H., Tanvir, K., Khan, M. A. B., Basit, I., Ul, Q., Ain, F. F., ... \&amp; Siddique, S. An Effective Approach towards Heavy Metals and their Effects on Different Organs of the Body.

15. Hussain, A., Rafeeq, H., Asghar, A., Ullah, S., Imtiaz, U., Ullah, H., ... \&amp; Ilyas, M. D. 
Combined inhibitory potential of Ammonium thiosulphate and 2-chloro-6-(trichloromethyl) pyridine on ureases activities.

16. Ghani, U., Bukhari, S. S. H., Ullah, S., Rafeeq, H., Saeed, M. M., Amjad, A., \&amp; Taufiq, T. (2019). A review on Nutraceuticals as a Therapeutic Agents. International Journal of Biosciences, 15(5), 326-340.

17. Naeem, M., Hayat, M., Azmi, U. R., Ahmed, S., \&amp; Irfan, M. (2019). Molecular Identification of Ten Palm Species using DNA Fingerprinting. Int. J. Pure App. Biosci, 7(1), 46- 51.

18. Ahmad, I., Khan, S., Naeem, M., Hayat, M., Azmi, U. R., Ahmed, S.,\& Irfan, M. (2019). Molecular Identification of Ten Palm Species using DNA Fingerprinting. Int. J. Pure App. Biosci, 7(1), 46-51. 14.

19. Naeem, M., Hayat, M., Qamar, S. A., Mehmood, T., Munir, A., Ahmad, G., ... \& Hussain, A. (2019). Risk factors, genetic mutations and prevention of breast cancer. Int. J. Biosci, 14(4), 492-496.

20. Shafiq, S., Adeel, M., Raza, H., Iqbal, R., Ahmad, Z., Naeem, M., ... \& Azmaai, U. R. (2019). Effects of Foliar Application of Selenium in Maize (Zea Mays L.) under Cadmium Toxicity. In Biological Forum-An International Journal 11(2): 27-37.

21. Usman, G., Muhammad, N., Hamza, R., Usman, I., Ayesha, A., Saqib, U., ... \& Fatima, Q. (2019). A Novel Approach towards Nutraceuticals and Biomedical Applications. Scholars International Journal of Biochemistry, 2(10), 245-252.

22. Naidu, K. A. (2003). Vitamin C in human health and disease is still a mystery? An overview. Nutrition journal, 2(1), 7.
23. Peter, S., Friedel, A., Roos, F. F., Wyss, A., Eggersdorfer, M., Hoffmann, K., \& Weber, P. (2016). A systematic review of global alphatocopherol status as assessed by nutritional intake levels and blood serum concentrations. Int. J. Vitam. Nutr. Res, 14, 1-21.

24. Pittas, A. G., Chung, M., Trikalinos, T., Mitri, J., Brendel, M., Patel, K., ... \& Balk, E. M. (2010). Systematic review: vitamin D and cardiometabolic outcomes. Annals of internal medicine, 152(5), 307-314.

25. Reboul, E., Richelle, M., Perrot, E., DesmoulinsMalezet, C., Pirisi, V., \& Borel, P. (2006). Bioaccessibility of carotenoids and vitamin $\mathrm{E}$ from their main dietary sources. Journal of Agricultural and Food Chemistry, 54(23), 8749-8755.

26. Schurgers, L. J., Teunissen, K. J., Hamulyák, K., Knapen, M. H., Vik, H., \& Vermeer, C. (2007). Vitamin $\mathrm{K}$-containing dietary supplements: comparison of synthetic vitamin $\mathrm{K} 1$ and nattoderived menaquinone-7. Blood, 109(8), 3279 3283.

27. Shearer, M. J. (2009). Vitamin K deficiency bleeding (VKDB) in early infancy. Blood reviews, 23(2), 49-59.

28. Wolf, G. (2001). The discovery of the visual function of vitamin A.The Journal of nutrition, 131(6), 1647-1650.

29. Yamada, K. (2013). Cobalt: its role in health and disease. In Interrelations between essential metal ions and human diseases (pp. 295-320). Springer, Dordrecht.

30. Zetterström, R. (2009). Nobel Prize 1937 to Albert von Szent- Györgyi: identification of vitamin $\mathrm{C}$ as the anti- scorbutic factor. Acta Padiatrica, 98(5), 915-919. 